Tesis. Año 14, 13(17), 2020, 221-242

\title{
Acercamiento a la tradición poética peruana: características y series en la poesía del siglo $\mathbf{X X}$
}

\author{
Wendy María Castillo Castillo \\ wendy.castillo@unmsm.edu.pe
}

\section{Resumen}

Una categoría como la tradición es parte funcional e importante dentro de la Historia de la Literatura, ya que es el medio por el cual se logra examinar el desenvolvimiento de una literatura a través del tiempo, desde su formación hasta la identificación de sus momentos de apogeo y madurez. Es más, no solo se limita a la literatura de un país o continente, implica un acercamiento diacrónico hacia los materiales que participan en la construcción discursiva, especies literarias, géneros, tópicos, temas articulados en los discursos principalmente (Maestro, 2014). Es ese sentido, al tratar la tradición poética se apela al conocimiento cercano y temporal del proceso de la poesía que nos permite conocer sus características constates; de ellas la modelización desempeña un papel funcional significativo. Así, se examina las materialidades del lenguaje en una selección de corpus poético perteneciente al siglo XX, de manera gradual y cronológica a fin de enfatizar el rol de la evolución.

Palabras clave: Historia literaria; poesía peruana; tradición poética; siglo XX; lenguaje poético.

\begin{abstract}
A category such as tradition is a functional and important part of the History of Literature, since it is the means by which it is possible to examine the development of a literature through time, from its formation to the identification of its heyday. and maturity. Moreover, it is not only limited to the literature of a country or continent, it implies a diachronic approach towards the materials that participate in the discursive construction, literary species, genres, topics, themes mainly articulated in the discourses. In this sense, when dealing with the poetic tradition, the close and temporal knowledge of the process of poetry is appealed to, which allows us to know its constant characteristics, of which the modelling plays a significant functional role (Maestro, 2014). Thus, the materialities of language are examined in a selection of poetic corpus belonging to the 20th century, gradually and chronologically to emphasize the role of evolution.
\end{abstract}

Key words: Literary history; Peruvian poetry; poetic tradition; twentieth century; poetic language. 


\section{Acercamiento a la tradición poética peruana: características y series en la poesía del siglo $\mathbf{x} \mathrm{x}$}

\section{La tradición poética y sus características}

En un contexto nacional, la tradición poética peruana - en cuanto almacenamiento de las obras, interacción de paradigmas, formación de modelos creativos y surgimiento de estilos personales- entabla una relación continua, dialogante e interactiva, que posibilita el reconocimiento. Este es un marcado rasgo contrastivo presente en la poesíay es imperativo para sistematizarla y configurar una nueva e integral perspectiva, es decir, un sistema poético; donde a partir de esta unidad sistémica (Tinianov, 1972) se valore tanto su heterogeneidad y sus variaciones como un todo, en su conjunto, en vez de continuar con las fragmentaciones e individualizaciones (poesía andina, nikkei, escrita por mujeres, afroperuana, etcétera) que incrementan la diseminación de la poesía peruana en grados tan dispersos que generan una desorganización caótica. Es esta la imagen que impera en los estudios literarios, logrando abrir más las brechas entre lo que es o no poesía en Perú.

La poesía, dada su materialización discursiva (oral, escrita, visual e impresa) conglomera dentro de sí una variedad densa y extensa de todo aquello - sea endógeno o exógenamente- que afecta al ser humano. Este hecho de por sí es significativo, porque revela el carácter universal y ficcional de este género, en cuanto proceso creativo de elaboración de poemas a partir de su experiencia e interacción con la realidad. Asimismo, subraya su universalidad, debido a que permite ampliar su dimensión frente a la arbitrariedad de los estudios literarios heterodoxos, para lograr subvertir o cuestionar su perspectiva heterogénea homogenizante (existencia de muchos sistemas poéticos coexistentes entre sí), fomentando la propagación de una multiplicidad de "tipos" o "sistemas" poéticos que confluyen al mismo tiempo dentro de la poesía peruana. Como resultado, se asumen particularidades e individualidades a modo de un todo diferenciador, un grupo que encierra subordinación y omisión al cortar la ilación y relacionalidad en pro de la reafirmación de identidades, por eso la categoría 
tradición se asume como un conocimiento saneado por completo, cuando en realidad implica un trabajo sistemático de años e indagación constante:

La tradición poética peruana arranca de muy antiguo. Los cronistas consignan cánticos y oraciones prehispánicas y en el folklore perduran joyas de un delicado cancionero erótico y campesino, cuyas traducciones al español han influido en los poetas cultos desde los tiempos de Mariano Melgar. En la actualidad, el incremento de las versiones castellanas de la literatura autóctona, especialmente las debidas a José María Arguedas, están dejando una huella visible en la obra de los más jóvenes. Se trasmite, salvando los siglos, un tono. Precisamente el tono triste y sentimental a que aludimos. Este viene, pues, desde lejos, desde muy lejos. (Salazar Bondy, 1997, pp.6-7)

Aquí, Salazar Bondy avala la existencia de una tradición poética que se remonta a los primeros momentos de su historia lírica; además marca la presencia de discursos elaborados en códigos ajenos al español, del proceso de la traducción y el modo en que pese a los rasgos que cada obra posee: en conjunto, todas estas forman parte de un todo, donde se puede advertir particularidades en común. Por consiguiente, configurar la poesía como un sistema, nos acerca a la comprensión analítica de su evolución; contrariamente, si apostamos por una dispersión de varias poesías peruanas se invisibilizaría las redes de sus textualidades pertinentes a cada etapa, tiempo y espacio de cada autor con su obra. Razón por la cual, se plantea la poesía peruana como un solo y unitario género literario (avalado en los postulados sobre historia literaria de Iuri Tinianov y Víktor Vinogradov), a partir del cual se examina e interpretan sus componentes de manera integral. Por lo que la tradición poética peruana se circunscribe en un marco cohesivo - en tanto conocimiento sobre el pasado sincrónico e instructivo de la poesía durante el tiempo en virtud de revelar el intricado complejo de su génesis- con el propósito de reparar con mayor proximidad los factores, hechos o estructuras de las obras, determinantes en la acción incesante de modificación y retroalimentación cuando se movilizan dentro de la tradición poética. Entonces, se obtiene información coherente, correlacional con su realidad evolutiva en función de evaluar la situación o dinámica presente en la poesía con el objetivo de elaborar proyecciones y examinaciones decisivas para los futuros escenarios poéticos.

La tradición poética peruana es un complejo vivo (Mukařovský,2014) que encierra e implica en su accionar: continuidad, tensión e historia al condensar la pluralidad de sus variaciones, sumada a las características que definen el sentido que la poesía ha desarrollado en el poesía, cada elemento coexiste entre sí. La tradición no se presenta ni desenrolla de manera lineal, principalmente a causa 
de la heterogeneidad transversal en toda la literatura peruana; por eso se identifican tres características:

\section{Contrastiva}

En atención a la naturaleza de la literatura peruana en cuanto un sistema, donde cohabitan de manera intercomunicativa varios subsistemas, la poesía no se escapa de esta contingencia; razón por la cual envuelve un espacio en común, donde se manifiestan ya sea en diversos o simultáneos momentos, diferentes escritores, tendencias, estilos, influencias y canales. Este último, exacerba su densidad, pues en Perú hay un pluriculturalismo arraigado, capaz de articular sus propios discursos a partir de su visión del mundo y de su lengua (Eielson, Salazar Bondy, y Sologuren, 1946); tal es el caso de la poesía asháninca, quechua, aymara, entre otras. Estas particularidades aunadas suscitan un ambiente tenso en el grupo poético que remarca las diferencias, haciendo colisión en las especificidades funcionales de la tradición; ella, gracias a estos contrastes, facilita tanto estructurar como organizar las etapas álgidas (críticas) y cúspides de la poesía, así como reconocer los motivos que a la vez de diferenciar una poética de otra, permite esclarecer los puntos repetitivos. Los contrastes no marcan un deslinde ni significan un rompimiento, en cambio, marcan el movimiento de los cambios en las obras de diferentes poetas en relación con los demás, también la de un solo autor.

\section{Oscilante}

La tradición es oscilante, dado que al converger un tránsito contrastivo se erigen características y propiedades que se imponen una por encima de los demás. A la par de, enfatizar la producción literaria de un poeta o grupos poéticos, esto en parte permite entender por qué hay una superposición de un listado "oficial" (canon) de obras representativas, que la crítica asume como parte de una tradición, no solo lírica. Aunque, por otra parte ayuda a hacer hincapié en los contrapuntos e hitos, así el 1922 fue un año cúspide en la lírica contemporánea debido a la publicación de Trilce, poemario representativo de César Vallejo. Tanto fue el impacto que causó en la academia que eclipsó no solo la aparición de obras posteriores, sino también aquellas que fueron publicadas ese mismo año, como Polirritmos de Juan Parra del Riego, La linterna de Diógenes de Alberto Guillen, Todo, todo es amor de Luis Benjamín Cisneros, por ejemplo.

\section{Modelizante}

Hasta el momento se repara la preeminencia de cualidades en apariencia contradictorias y distantes, pero todas ellas en unidad responden de modo consecuente a la lógica que subyace en la poesía en su diálogo con la tradición. En 
tal sentido, lo modelizante es aquel carácter manifestado a través del lenguaje poético, en el cual se constatan los niveles de vinculación e interrelación entre las diversas poéticas existentes. Pone en relieve una gama de estructuras que exponen el nexo comunicativo y relacional presentes en los poemas en el transcurso del tiempo y la historia de la poesía del país. Por tanto, al analizar el lenguaje desarrollado en las poéticas aparecen las series evolutivas (densidad metafórica y plasticidad introspectiva) que señalan el tránsito evolutivo y la naturaleza dominante de la tradición, que en este caso, es modelizante, oscilante y contrastiva, donde la primera es la principal al configurar las series.

\section{Las modelizaciones del lenguaje poético}

El lenguaje es la materia prima de la Literatura, sin ella todo proceso de creación resultaría, en esencia, imposible de realizar. Aún más, cuando se trata del género poético, pues como bien sostiene Jean Cohen (1973) sin lenguaje no hay poesía (Ricoeur, 1980). En atención a lo cual, aquel se configura como el elemento desencadenante y operativo del discurso lírico, dentro del cual se despliega una sucesión de mecanismos, estrategias que dotan de vida, identidad e intimismo a los poemas que, en el contexto de la poesía peruana se vuelve más intrincado al conglomerar y reflectar sus particularidades. En consecuencia, para evidenciar tanto la condición como el carácter de la tradición poética es necesario partir de la reflexión e identificación de las series evolutivas plasmadas en la articulación del lenguaje en los poemas: estas encierran en su expresividad una gradación de sentidos estructurales incesantes en el transcurso de los años (Vinogradov, 1978). Por eso, pese a la aparición o sucesión de paradigmas, estilos e influencias, se revela una gama relacional, significante; una modelización del lenguaje que focaliza la correlación dialogante entre las poéticas circunscritas - en este caso singular del estudio-, la etapa contemporánea de la poesía peruana, donde se manifiestan tres modelizaciones: la esteticista, situada en los años 30 hasta los 50, la identitaria, transversal a lo largo del periodo, y la referencial, que comprende los años 60 hasta los 80. En esta oportunidad, nos vamos a remitir solo a la primera: la esteticista.

\section{La modelización esteticista en la poesía de los años 30 al 50}

Cuando nos referimos a modelización esteticista del lenguaje poético, priman dos nociones medulares. Una que comunica al mismo tiempo de revelar la gama significativa serial común en las poéticas del período contemporáneo; también, al tratarse de una coexistencia e interrelacionalidad con varias series, algunas van a sobresalir o ser dominantes por encima de otras, sin conllevar a un rompimiento ni mucho menos a una separación, pues se trata de un movimiento con graduaciones vinculantes entre ellas. De tal forma que, en los primeros 40 años de la poesía peruana predomina la modelización esteticista. En segun- 
do lugar, por el término esteticista se entiende a las estrategias, mecanismos y demás recursos que exaltan la cualidad maleable, moldeable del lenguaje, sea complementado por modelos de estrofas, rimas, ritmos imágenes, etcétera. E1 poeta se preocupa por materializar un discurso fino, exquisito donde concreticen el grado de conocimiento y técnica de los escritores en acción con sus obras, mientras entabla una conexión cercana con el poema, mas no es un cuidado o representación estética vana, ni vacía, ya que muchos de los poemas exponen un intimismo identificable en el ser humano, aparte de trabajar temas universales como la tristeza, el dolor, el amor, entre otros. De modo que, para aprehender con mejor precisión su desplazamiento se le examina a partir de sus dos estructuras básicas:

\section{a)Densidad metafórica}

Entendida la metáfora como una estrategia del lenguaje poético encargada de desplegar mecanismos de plasticidad expresiva con el propósito de romper las barreras del código lingüístico, a partir del empleo de distintos principios de relacionalidad - comparación, equivalencia, analogía y semejanza-. (Castillo, 2019 , p. 74). Admite en su composición acoplar un tejido intranominal, donde confluye una profundidad de sentidos, una interiorización de perspectivas e ideas, tal como se muestra en este poema de Martín Adán (1908-1985):

Nací en una ciudad, y no sé ver el campo.

Me he ahorrado el pecado de desear que fuera mío. 65

En cambio deseo el cielo.

Casi soy un hombre virtuoso, casi un místico.

Me gustan los colores del cielo porque es seguro que no son tintas alemanes.

Me gusta andar por las calles algo perro, algo máquina, 70 casi nada hombre.

No estoy muy convencido de mi humanidad; no quiero ser como los otros. No quiero ser feliz con permiso de la policía.

Ahora en las calles hay un poco de sol. 75

No sé quién se lo ha llevado, qué mal hombre, dejando manchas en el suelo como un animal degollado.

Pasa un perrito cojo - he aquí la única compasión, la única caridad, el único amor de que soy capaz.

Los perros no tienen Lenin, y esto les garantiza una vida 80 humana pero verdadera. 
Andar por las calles como los hombres de Pío Baroja

-(todos un poco perros)-.

Mascar huesos como los poetas de Murger, pero con serenidad. 85

Pero los hombres tienes posvida.

Por eso dedican su vida al amor del prójimo.

El dinero lo hacen para el tiempo inútil, el tiempo vacío ... 90

$$
\text { (Adán, 1980, p.12) }
$$

Estos fragmentos que forman parte de "Poemas de underwood" hay dos metáforas in absentia o pura, dominantes. Se dispone una identificación y relación yuxtapuesta entre perro con el hombre, pese a su carga nominal diferente en los versos son equitativas, en un grado de interdependencia que conforme el desarrollo del poema se intensifica cada vez más, al punto de devenir en una sola existencia. A partir del verso 78 hasta el 89, con progresión la voz poética despliega un proceso de reidentificación iniciado con el sentimiento de compasión que despierta en él la representación de un perrito herido, cojo, cuyo padecimiento repercute en el sujeto. Comienza a meditar, por medio de la comparación entre hombre/perro, así este no se somete a ideologías ni políticas (Lenin), puede disfrutar de los placeres de la vida, sin egoísmos ni trifulcas (Murger) o continuar su andar pese a ser consciente de la insatisfacción de la realidad y la verdad (Baroja):

Diógenes es un mito - la humanización del perro.

90

El anhelo que tienen los grandes hombres de ser completamente

perros. Los pequeños hombres quieren ser com-

pletamente grandes hombres, millonarios, a veces dioses.

Pero estas cosas deben decirse en voz baja — siento miedo

de oírme a mí mismo.

Yo no soy un gran hombre - yo soy un hombre cualquiera

que ensaya las grandes felicidades.

Pero la felicidad no basta a ser feliz.

El mundo está demasiado feo, y no hay manera de embellecerlo.

(pp.12-13)

Si solo el texto concluyera que el perro es mejor que el humano, estaríamos ante una metáfora lineal, con una relacionalidad directa y derivativa, pero cuando se presenta una densidad metafórica implica vehemencia e ímpetu; en otras palabras, hay tanto capas como grados dentro de las metáforas perro-hombre. 
En el nonagésimo verso la transición entre ambos está en una penúltima fase al adjudicarse rasgos humanos, reafirmado con la referencia a Diógenes. En tanto, aquel con la competencia de lidiar, aceptar y asumir de buena manera la vida, así aquellos hombres capaces de comprenderla desean un cambio dentro de sí "el anhelo que tienen los grandes hombres de ser completamente perros" ( p. 13). A diferencia, de los más débiles e indiferentes (pequeños hombres) que se dejan atrapar por la apariencia, banalidad y vacuidad de esa horrorosa realidad que habitan.

La voz poética, al definirse como "hombre cualquiera" acepta por un lado sus limitaciones (imposibilidad de ser completamente perro), pero por otro, alcanza un estado de consciencia ardua, permitiéndole descifrar la imagen del perro y la depreciación del hombre, al tiempo de sus esferas sociales, la poesía, la belleza o la felicidad. Por tanto, el perro no es el animal doméstico ni la bestia cuadrúpeda sujetado a los múltiples correlatos de la sociedad; es el ser libre, con sabiduría sobre su entorno - porque conoce sus verdades a la vez de aceptarlas sin problema alguno, sea oscura, injusta, buena o mala- se mantiene imperturbable, casi estoico. Otro vanguardista coetáneo a Martín fue Enrique Peña (1904-1988); ambos, pese a ser grandes modelos del vanguardismos, tienen y crean sus propios temas que conforman su estilo individual, sin distanciarse de la tradición de la cual son parte. Esto se verifica por las correlaciones seriales, en su caso la densidad metafórica, aborda elementos de la naturaleza:

En esta soledad, en esta dulce alegría de soledad, un animal que muerde nieblas, que está contento de sus recuerdos.

Una mano en el aire dibuja flores y crecen, crecen como espumas de oro.

A la orilla de este sueño llegan los peces de los mares antiguos, constelados de topacios.

En esta soledad nazco y envejezco; tengo mil años y me piso las barbas.

Rabia de gorila salvaje, clavo mis garras en las paredes 10 de tu ausencia. (Peña, 1977, p. 88)

En los primeros once versos la soledad es el hilo conductor, a medida que ella crece cuaja en el sujeto lo deforma, haciéndole incurrir en compor- 
tamientos extremos. La densidad de la metáfora emana baja tres formas: el de la intensificación "Un mano en el aire dibuja flores y crecen, crecen como espumas de oro", la catacresis junto a la enumeración de imágenes naturales (flores, niebla, peces, topacio) se anudan en un clima asfixiante que sobrepasa al yo lírico, al punto de sembrar en él la duda de estar ante una realidad tan abrazadora o está en un sueño con tintes surrealistas, donde tiempo y espacio crecen raudamente conforme conserva su lucidez. Luego, está el plano de la delimitación que lo amarra hacia una racionalidad, sin perder su lado sensible, acercándolo más a la autorreflexión; por tanto, es capaz de recibir la soledad en él, así como el tiempo en su cuerpo "En esta soledad nazco y envejezco; tengo mil años y me piso las barbas". Por último, la animalización, resignado a la soledad, todavía no es capaz de asimilar esta situación inevitable, por eso lucha, resiste en su afán por suplir una ausencia. Poco a poco se ve consumido, pero se mantiene lúcido:

Me curvo como un animal de museos, con escamas, sin sexo, asqueroso.

En esta soledad me arrastro y dejo babas.

En esta soledad, a veces soy, también, un trébol, un hilo de lluvia.

Pienso en el rapto de la luna por los ángeles bárbaros.

O en los ojos asombrados de la anunciación.

Yo desespero amigos de esta soledad. Yo estoy contento amigos de esta soledad.

En estas últimas partes hay una oscilación entre desesperación y admisión de la soledad para consigo, para con lo que le rodea. Fluctúa una efusión de sentimientos e ideas que lo llevan a interiorizarse con fuerza; es cuando contempla su mundo, la situación en que se encuentra; sabe la imposibilidad de escapar. Motivo por el cual, a veces se siente un animal, otra fragilidad, un ente sensitivo e inquisitivo de su situación, sobre los objetos — de dónde vienen o qué son- sin olvidar este abandono inevitable, aunque fundamental para su existencia, que a ratos lo desespera, y otros lo alegra al saberlo, al ser por completo mediante la soledad. Igualmente, en el siguiente poema de Javier Sologuren (1921-2004) se encuentra esta estructura: 
Yo, Velador,

me confieso a ti,

Noche,

bajo mi lámpara

(Tú conmigo)

Yo, Velador,

me confieso a ti,

Lámpara,

bajo la noche,

(Tú conmigo).

(Sologuren, 2004, p. 176)

Marcado desde el inicio, el yo poético se perfila bajo la imagen del velador, un atento y vigilante sujeto que exterioriza meditativamente su existencia. En virtud de ello, ambos, noche/lámpara, son la metaforización de los estados críticos del individuo, esta permutación que por momentos le brinda estabilidad, lucidez (lámpara); otros lo hacen cuestionar, alterar hasta desequilibrarse (noche). De ahí, la concurrencia de las metáforas orientacionales. La acción de contemplación no se enmarca solo en cuestiones del individuo, también envuelve su habilidad creadora:

Yo, Velador,

me confieso en ti,

Página,

bajo mi frente blanca

(Tú conmigo)

Yo, Velador,

me confieso a ti,

Sueño,

criatura mía,

remota,

bajo la noche,

la lámpara

la página blanca...

(Conmigo tú, por siempre). 
Las estrofas finales terminan por completar la idea detrás del tú. Ya se ha dejado en segundo plano lo correspondiente a la dimensionalidad de la conducta; ahora el centro de vigilancia se da en la problemática de la incompletitud y lo inefable, el protagonista puede fabricar sueños, criaturas, incluso realidades porque tiene la protestad de manipular la página blanca según sus preferencias. Mas en tiempos de pesadumbre se da cuenta de que habrá un espacio, un vacío imposible de llenar, que no se puede siquiera decir, solo se siente y percibe. Es en ese momento que se encuentra con la limitación e imposibilidad expresiva, tan natural como inherente en todos.

Con la materialización de la densidad metafórica, el lenguaje del poema desencadena capa, tras capa de sentidos, sensaciones y perspectivas que conformen nos acercamos a la aprehensión de cada una de ellas obtenemos una interpretación más integral e intensa del texto:

\section{Describo el invierno}

\section{A José Miguel Oviedo}

Conozco bien estos pesados guantes de albayalde

porque antes vi su rastro

cubrir otros días de lujuria y beatitud,

la rauda pareja de lobos

de cuyo lecho nacen como quejidos o espasmos

humedades, virus, toses.

Sé cómo el tiempo cose sus lentejuelas,

en la loca ropa de ayer,

cómo se agrietan sombras de muebles y paredes,

cómo el corazón se encharca y lentamente

trae un recuerdo desde la antigüedad.

Repito mi historia en el duro piano de invierno:

mi sangre es toda blanca

cuando las brumas de junio en los parques

tuercen el cuello al cisne de la fecundación.

$$
\text { (Salazar, 1965, p. 22) }
$$

Al evocar y describir el invierno, nos adentramos hacia representaciones fuertes que bordean la crudeza al establecer un ambiente agreste, aquí incluso la naturaleza lastima a las personas, en el transcurso de la desnudez de sus más recónditos vicios y conductas en la sociedad día a día. La dureza de este invierno pone al descubierto la pesadez del tiempo y la vulnerabilidad de los hombres 
frente a ella, sin la posibilidad de escaparse "el tiempo cose sus lentejuelas en la loca ropa de ayer"; esto conduce a la develación de la miseria. Es la impiedad latente e ineludible, se torna más agresiva en temporadas aciagas, degradando aquello que se encuentra a su paso sea vivo o no. Asimismo, uno de los mecanismos más empleados durante la construcción poética es la relación contrastiva verificable en "Metamorfosis" de Alejandro Romualdo (1926-2008):

El toro en buey. El buey en instrumento.

El dios en cisne. El cisne en energía.

El río en mar. El mar en joyería.

El lamento en dolor. La voz en viento.

La muerte en fuego. El fuego en nacimiento.

El hombre en dios. El dios en agonía.

El llanto en pan. El pan en alegría.

El vino en agua. El agua en alimento. (1986, pp. 68-69)

En estas dos estrofas iniciales las múltiples metáforas e imágenes tienen la función de explicarnos la transición entre materia, objeto y ser hacia una fase superior, una evolución que puede ser positiva o negativa, a manera de modelos. De ellos, se resalta el trance del hombre a dios; ese deseo humano ferviente ilustrado a lo largo de la historia de la civilización por alcanzar la divinidad; sin embargo, se muestra una contraparte a pesar de los rasgos divinos que pueden ser mejores a las limitaciones de los hombres hay algo inherente en este último para siempre, el dolor, el sufrimiento. En adición, se acentúa la ciclicidad de la existencia, llena de complementariedad y contradicciones, en otras palabras, se es y no, se siente y no:

Verás sobre la tierra o sobre el cielo, romper con alas duras el macizo

aire de amor que Amor hizo a tu vuelo.

La misma voz que ordena, desordena.

El mismo amor que te hizo, te deshizo.

Y el hombre es lucha. Y en la lucha pena.

Se adentra más a esta duplicidad que convive en los hechos, cosas y personas, ahora se trata de los efectos que se atan e hilvanan en cada acción. Así, alguien que en principio fue calma, paz para otro también, puede ser destrucción en un solo instante; tal como ocurre con el amor lo bueno/malo en un solo 
y mismo sentimiento. Pero al tener la libertad de escoger su camino, edifica su destino, por ello, al optar por la impasibilidad, la lucha acepta sus consecuencias, la tristeza, pues al fin y al cabo toda acción tiene una reacción.

Hasta ahora, esta selección de poemas aparte de incidir en la dimensionalidad del uso del lenguaje comparte una armonía en el esquema de los versos. Es cuando elementos como la estrofa, el ritmo y la rima, adquieren igual relevancia para la composición de las palabras; es más, la atención de ambas dimensiones es sustancial para el procedimiento del análisis interpretativo (Greimas, 1976). Aquellas particularidades son plasmadas con singularidad maestría en este texto de Juan Gonzalo Rose (1928-1983):

\section{Letanía del solitario}

Cada tarde te pierdo, como se pierde el tiempo, o la esperanza.

Cada tarde, definitivamente,

te pierdo como se pierde la paciencia.

Cada tarde dices no.

Mueves la cabeza y dices no.

Mueves la tierra y dices no.

No mueves los labios y tu silencio dice no.

Infatigablemente, cada tarde, mi café solitario obscurece el planeta

(Rose, 2007, p. 77)

E1 hablante lírico despliega un soliloquio, cuyo leitmotiv es la pérdida (ausencia) de una persona muy querida. Al inicio, su falta trae como resultado el razonamiento acerca de lo mensurable que puede llegar a ser la realidad, verbigracia el tiempo transcurrido y destinado para ser utilizado de una manera en particular: jamás volverá. Los sentimientos, los objetos e incluso lo abstracto no son renovables, se pierden una vez destinados a un fin en particular; esta insistencia malsana reflejada con claridad en el paratexto, lentamente lo conduce a la agonía, a un sufrimiento que es la expresión directa de la incapacidad (terquedad) por asumir la fugacidad que habita en la vida, sumado al no saber lidiar con el abandono, ocasionan el desborde de su dolor. Se siente más solo 
que nunca, puesto que aún no sabe que tiene a esa soledad como compañera perpetua.

\section{b. Plasticidad introspectiva}

Consiste en la exacerbación vívida del individuo en el discurso, donde su experiencia o ideología (postura), según sea la naturaleza del poema, se localiza en primer plano y es enfatizada aún más a través del empleo de figuras, juegos de palabras, sonidos, sinestesia, ritmos - entre otros elementos que en conjunto resaltan las vivencias del sujeto- cuya marca de voz no excluye a otras personas gramaticales. Se consolida un intimismo fuerte e intenso, vigorizado con la moldeabilidad del lenguaje apoyado en la efusión, en su capacidad de ser manipulable al adquirir diversas formas, dimensiones y extensiones. En suma, la plasticidad de las palabras en el discurso poético. Es común que la plasticidad introspectiva sea articulada en primera persona con un hablante lírico como protagonista, pero no excluye la intervención de otras personas bajo una voz colectiva, por ejemplo. El siguiente poema de Adán se encuentra dentro de la primera situación:

Sí, yo vengo a vivir a cada cosa, y vivo.

Yo vivo como el aire, que se está a cada cosa.

Vivo con el color con que la mariposa

Vuela o el ventarrón de la cuerna del chivo.

Vivir me es agitarme, y por esto lo escribo,

Para que quede algo ... como el perro que hoza

Interminablemente, como en dios o en su esposa,

Como buscando el propio hueso de que es cautivo.

Sí, vivir... me lo vivo y por esto me muero.

Y hay un poco de día en la ventana y gimo,

Porque en ello me topo con lo eterno que quiero.

¡Eterno de centímetros cuadrados y que infierno! ...

¡Eterno de mi gesto con que bramo y me eximo! ...

¡Eterno yo, que vivo y, muriendo, me espero! ...

$$
\text { (Adán, 1980, p. 404) }
$$

Las dos primeras partes del soneto perfilan el sentir del hablante lírico, que conforme se presentan los subsiguientes versos degrada la idea que tiene de sí. Ahora bien, vemos cómo empieza por celebrar el acto de la vida, puesto que le da la sensación de libertad sin barreras hasta el punto de tener la potencia 
suficiente de vitalizar cosas u objetos que lo rodean, pero el incesante ritmo derivado de aquel comienza a mellar su estabilidad. Se da paso a la fugacidad de la existencia avivada por la progresiva cosificación de la vida, esto se traduce en un desgaste anímico, evidenciado en el uso reiterado de la comparación con el perro, el hueso y dios. El ambiente termina por llevarlo a una inquisición introspectiva del yo poético, sumergiéndolo en la incertidumbre; esto continúa en las posteriores estrofas, aunque ahora se torna en un soliloquio. Es cuando entra el contrapunto, la polaridad negativa de la vida, la muerte, ella se revela a manera de una parte indivisible e inevitable, su carga ejerce presión en la perspectiva "Sí, vivir...me lo vivo y por esto me muero" convirtiéndose en un dolor efervescente (gimo, me eximo). La idea sobre la eternidad asume el sentido del marasmo, al parecerle interminable el tiempo de seguir viviendo, de su vida, solo le queda aguardar su fin.

La exageración metafórica o catacresis se da a conocer en la exasperación del sujeto:

\section{VII}

Así yo voy caminando, a tientas hermano, a tientas en esta noche sombría que nunca acaba.

Manos que pudieron ser en esta hora acariciadas, crispándose están de angustia en la noche larga.

(Peña, 1977, p. 29)

En este texto de Peña se deja de lado los ornamentos y el histrionismo del paradigma vanguardista para dar pie al lenguaje sencillo pero intenso, donde tenemos a un locutor que entabla una comunicación con su hermano, así le manifiesta un sinsabor, una incompletitud que lo perturba. Primero, se presume que el medio es el causante de esto, a causa de que es descrito de manera agreste; sin embargo esta posibilidad queda en segundo lugar al centrarse en el cuerpo, mediante la presión ejercida por la sinécdoque. Como resultado, el locutor apela a lo patético a presenciar y entender una descomposición que trasciende al cuerpo, mientras vulnera su alma. La pesadumbre se asoma casi al instante en el que la presencia de la noche se esparce, haciéndole caer en una crisis nerviosa:

¡Ah, no atino a palpar nada!

Y cuando al fin doy un grito de alegría, me convenzo 
que me he palpado a mí mismo, a mí, que estoy de regreso.

Dos yo, doble eternidad:

uno, alma mía, que viene,

y otro, alma mía, que va.

(p. 29)

El individuo se está desatando, es incapaz de sentir, lastimándolo más; tanto que se expresa con vehemencia, grita en su intento por comprobar si fehacientemente está sucediéndole esto, la depreciación de sí mismo. Como resultado, se encuentra con un efecto espejo, se halla así mismo; el re-encontrarse deviene en la ciclicidad de la vida impuesta en cada persona, sin poder eludirla. Aparece esta dualidad perpetua (alma/consciencia), la primera está dentro del imaginario, en lo eviterno; por ende, no lo desampara; en cambio la otra es frágil, pasible de desaparecer en el tiempo. La plasticidad exterioriza el lado más sensible e inestable del ser humano:

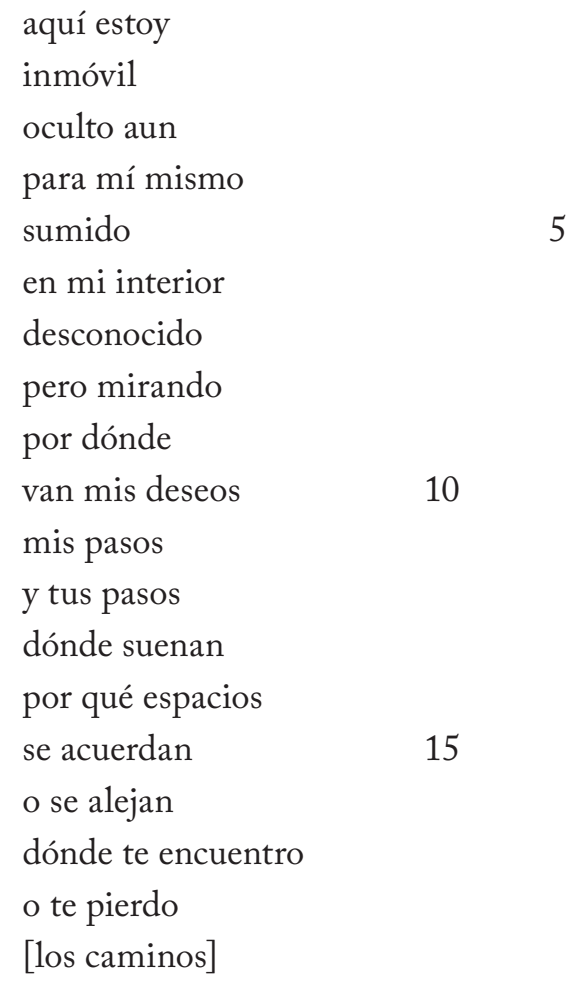

(Sologuren, 2004, p. 200)

Se conforma una voz masculina definida que cavila sobre su condición, se ha disgregado del mundo. Hay rasgos de inestabilidad posicionados por encima 
de la voz lírica, advirtiéndose en la dispositio del poema, se subvierten los estándares gramaticales no hay comas, puntos, ni pausas, con que se arma un medio voluble tanto en la forma como en el fondo del texto. No obstante, a diferencia de los anteriores poemas, aquí se nombra a un segundo sujeto, pese a estar sumergido e inmerso en su interioridad hay un anhelo por no desprenderse de él o ella, de seguir atado a este individuo. Al estar refugiado en su interior, no es gratuita la imposibilidad de conocerse, pero no lo afecta por eso todavía mantiene su atención en dos cuestiones: descifrar el sentido escondido detrás de su comportamiento, qué le motiva a hacer o no algo; esto sin desviarse de su objetivo por mantener una relación con la persona, comprobar si aún queda vínculo entre ambos o es que lo ignoto se encarga de seguir rompiendo los nudos que alguna vez los unieron con firmeza. Por otro lado, dentro de esta estructura se acentúa la polaridad o confrontación de elementos, muchos de los cuales cruzan la frontera de lo armónico — en el sentido ortodoxo del término- mostrando el de la miseria:

\section{Close up}

Me pongo en pie vacilante, sufro un eclipse de suicida. Algo en mi pecho pudrióse, algo, lodazal o cisne, fermentó al soñarlo.

¿Fui madriguera o ápice? ¿Algo como una polvorienta digestión descifró mi persona impersonal?

Claustro es la calle, secreta

mofa la acidulada aurora, negra piedra la luz en mi ventana. 10

Zozobra cuando mis hélices giran y sin tenerlo pierdo el día.

(Salazar Bondy, 1965, p. 10)

El paratexto nos anticipa el hilo conductor de estos versos pertenecientes a Salazar Bondy, el sustantivo en inglés close up denota el acercamiento íntimo y examinador sobre algo o alguien de modo introspectivo. Desde el comienzo, el yo lírico está inquieto, consumido por el desencanto; es un ser suficiente capaz de causarse daño. Motivo por el que el cansancio se adueña de él, tanto de sus emociones como de su alma, lamenta con hondura este quiebre que lo carcome y conduce a subestimarse hasta cosificarse. Esta acción es clave, inclusive trastoca la disposición en el poema, porque el hemistiquio del quinto verso exaspe- 
ra la degradación antropológica: "Fui madriguera o ápice? ¿Algo/...”. Asimismo, los adjetivos están en una función patética (impersonal, negra, acidulada) conformando el campo semántico de la desolación. La situación es tan densa en el hablante que se pierde la noción del espacio.

En la plasticidad introspectiva, también se encuentran discursos opuestos a la aflicción, ya que la interioridad contiene una amplia variedad de sentimientos y experiencias. En el siguiente caso estamos antes momentos de alegría, casi deviene en un estado de euforia:

\section{A puro pulso}

El cauce, el agua, la corriente, el río, el reflejo, la luz, el rayo ardiente,

la llama, el fuego, el sol incandescente, la órbita, el espacio y el vacío.

Si llegar por el cauce al desvarío 5 es alcanzar el límite luciente, hay que subir, crecer en el torrente y llegar por el agua hasta el rocío. Perfectamente pájaro es mi vuelo. Profundamente barro, mi escultura.

Terriblemente cauce, mi deshielo.

¡Baje el dolor y cave sepultura!

¡Surja placer y ruede por el suelo!

¡Crezca el amor y hosáneme la altura!

(Romualdo, 1986, p. 65)

A diferencia del poema de Sologuren, donde la desorganización de los versos se correlaciona con el contexto temático e íntimo disfórico, aquí Romualdo nos introduce a un poema muy estilizado, tanto en sus palabras como con la disposición de los versos del poema. Es un soneto con rima consonante (ABBA ABBA CDC CCD), el texto evoca un ambiente ecuánime, bondadoso, que al entablar un nexo con el locutor interviene en su desenvolvimiento diario, quien es consciente del lado indómito propio de ella, pero la acepta y transforma en un soporte esperanzador: "Si llegar por el cauce al desvarío/ es alcanzar el límite luciente, /hay que subir, crecer en el torrente" (p. 65). Las metáforas naturales (pájaro, río, cause) remarcan la integración de la esperanza, una lumi- 
nosidad en la vida de los hombres y mujeres dadora de vitalidad, de esta manera se da paso a un paralelismo entre ambos: "Perfectamente pájaro es mi vuelo / Profundamente barro, mi escultura/Terriblemente cauce, mi deshielo". Claro que esta no nos lleva hacia su idealización, por el contrario se tiene en cuenta la fragilidad incrustada en las personas, pero controlable, puede transformarse y expresar la belleza empática. La tercera estrofa brinda un mensaje de batalla y fe. El dolor es inevitable, el placer transitorio y el amor alcanzable, por eso nos dice el hablante que podemos mantenernos fuertes, con vida ante el ritmo variante del destino.

Si con Romualdo los elementos de naturaleza adquieren un rol imperativo decisivo en el ser humano, en el siguiente poema de Rose, el destinatario es el origen del discurso:

\section{Cadena de luz}

No debería hablarte de estas cosas.

Debería decirte:

La mañana es bella.

La tarde es bella.

La noche es bella.

Y al escucharme, tú sonreirías;

y al verte sonreír, mi propio corazón sonreiría.

Y al vernos sonreír acaso hasta la vida también sonreiría ...

$$
\text { (Rose, 2007, p. 72) }
$$

Al inicio señalamos que la plasticidad introspectiva no engloba tan solo a la primera persona o a un protagonista decretado, aquí vemos cómo el hablante lírico entabla comunicación con otra persona, a quien se dirige hasta el último verso. Hay eventos y circunstancias en el devenir que son desventurados, propios de los individuos, aunque en vez de ahogarse o discurrirse hacia monólogos con tonalidades existenciales, el sujeto poético se hace cargo de ella de modo frontal. A partir de esto, opta por decirle a su destinatario que la belleza es omnipresente, se le puede apreciar en los contrastes de la sociedad, el objetivo es impresionarlo con el poder de las palabras hasta transformarla en una verdad factible, viva y palpable, donde la felicidad de alguien sea la de otro y viceversa. 
Así, ambos arman la posibilidad de ser felices, sin tormentos ni divagaciones, simplemente ser.

En suma, con estos análisis se advierte cómo la modelización esteticista se alimenta de las primeras etapas — formativa/desarrollo - de la poesía en Perú, en la que escritores como Manuel González Prada, José María Eguren, Abraham Valdelomar y César Vallejo fueron figuras sustanciales en el cimiento de las bases técnicas, estéticas e ideológicas del género poético. A partir de ellos se producen nuevos discursos que prestan atención a los planos del poema. $\mathrm{Du}-$ rante los próximos años se verá un desplazamiento conflictivo de estas particularidades, ocasionando la subordinación de un plano (contenido) en desmedro del otro; esto en síntesis es la esencia de la segunda modelización, la referencial.

A modo de conclusión, la tradición como categoría de la Historia de la Literatura encierra el movimiento incesante y oscilante en su definición, pero también incluye la noción de ruptura, dado que durante este desenvolvimiento rítmico ciertas obras logran producir escisiones en el interior de ella, sin perder su dominio con la misma; tal es el caso de las obras de Alejandro Romualdo y Javier Sologuren. Asimismo, en el proceso evolutivo de la poesía peruana, al igual que su literatura en general, el elemento más distintivo e identificable es la heterogeneidad (Cornejo Polar, 2011), esa concurrencia de múltiples fuentes e influencias que convergen al unísono, pero que no suponen ni implican una división o clasificación de varias poéticas. Por el contrario, estos contrastes ponen en manifiesto, por un lado, su circunscripción como el conjunto sistémico, integral y tensional que es la poesía peruana, mientras que, por otro, expone el estado de su tradición.

\section{Referencias bibliográficas}

Adán, M. (1980). Obra Poética. Lima, Perú: Edubanco.

Albaladejo, T. (1991). Retórica. Madrid, España: Síntesis.

Arduini, S. (1993). La figura retórica como universal antropológico de la expresión. Estudios de Literatura, (18), 7-18.

Bobes, C. (2004). La metáfora. Madrid, España: Gredos.

Castillo, W.M. (2019). Aproximaciones a la retórica quechua: El caso de la poética del desarraigo en Jarawi de Dida Aguirre García. (Tesis de licenciatura). Universidad Nacional Federico Villarreal.

Cohen, J. (1973). Estructura del lenguaje poético. España: Gredos.

Cornejo Polar, A. (1989). La formación de la tradición literaria en el Perú. Lima, Perú: CEP.

Cornejo Polar, A. (2011). Escribir en el aire: ensayo sobre la heterogeneidad sociocultural en las literaturas andinas. Perú: Centro de Estudios Literarios Antonio Cornejo Polar. 
Eielson, J., Salazar Bondy, S., \& Sologuren, J. (1946). La poesía contemporánea del Perú. Lima: Cultura Antártica.

Greimas, A. (Ed.). (1976). Ensayos de Semiótica Poética. Barcelona, España: Planeta.|

Maestro, J. (2014). Contra las musas de la ira. El materialismo fllosófico como teoría de la literatura. Oviedo, España: Pentalfa.

Mukařovský, J. (2014). Standard language and poetic language. En: Chovanec. (Ed.), Chapters from the History of Czech Functional Linguistics (pp. 41-53). Masarykova, República Checa: Masarykova univerzita.

Ricoeur, P. (1980). La metáfora viva. Madrid, España: Cristiandad.

Romualdo, A. \& Salazar-Bondy, S. (1957). Antología general de la poesía peruana. Buenos Aires, Argentina: Librería Internacional.

Peña, E. (1977). Obra poética. Lima, Perú: Mejía Baca.

Romualdo, A. (1958). Edición extraordinaria. Lima, Perú: Cuadernos trimestrales. Romualdo, A. (1974). En la extensión de la palabra. Lima, Perú: Labor gráfica.

Romualdo, A. (1986). Poesía integra. Lima, Perú: Viva voz ediciones.

Rose, J. G. (2007). Obra poética. Lima: Instituto Nacional de Cultura (INC).

Salazar Bondy, S. (1997). Mil años de poesía peruana. Lima: Populibros.

Salazar Bondy, S. (1965). El tacto de la araña. Lima. Lima:Casa de la Cultura del Perú.

Sologuren, J. (2004). Vida continua, obra poética. Lima: PUCP.

Tinianov, I. (1972). El problema de la lengua poética. España: Siglo XXI.

Todorov, T. (1978). Teoría de la literatura de los formalistas rusos. España: Siglo XXI.

Vinogradov, V. (1978). Sobre la estilística. España: FCE. 